\title{
The informational relevance of key audit matters ${ }^{*}$
}

\author{
Edilson Divino Alves Júnior ${ }^{1}$ \\ (D) https://orcid.org/0000-0002-4059-2720 \\ Email: edilson.junior@alianzo.com.br

\section{Fernando Caio Galdi²} \\ (D) https://orcid.org/0000-0001-6231-0010 \\ Email: fernando.galdi@fucape.br \\ ${ }^{1}$ Alianzo, Departamento de Auditoria, Goiânia, GO, Brazil \\ ${ }^{2}$ Fucape Business School, Departamento de Contabilidade e Finanças, Vitória, ES, Brazil
}

Received on 10.05.2018 - Desk acceptance on 11.06.2018 - $3^{\text {rd }}$ version approved on 06.13.2019 - Ahead of print on 11.07.2019

Associate Editor: Eliseu Martins

\begin{abstract}
This paper aims to investigate whether the key audit matters (KAMs) contained in the annual standardized financial statements (SFSs) of Brazilian listed companies have contributed with informational relevance for investors. The study fills a gap in the literature by evaluating the Brazilian market's reaction to the disclosure of the information contained in the KAMs, which became mandatory for listed companies to disclose in their financial statements as of the 2016 fiscal year. The topic under analysis is of practical relevance as the use of KAMs in the independent auditor's report is growing and expanding to other publicly-held companies in addition to listed ones. This study provides a contribution to the Brazilian capital market regulator (Comissão de Valores Mobiliários - CVM) and the Institute of Independent Auditors of Brazil (Ibracon) regarding understanding the impacts of the new auditor's report, thus enabling the improvement and expansion of this mechanism. For the analysis, we use the event study methodology, which consists of evaluating how information influences the market in a particular period associated with the occurrence of a disclosure event. To do so, we used the variation in the sum of the daily abnormal returns of each company on the days that form part of the information disclosure window. The results of this paper indicate the consistency of the informative content of the financial statements with KAMs, insofar as the variation in the cumulative abnormal return of the companies analyzed is positively associated with the cumulative returns in the information disclosure window for the SFSs following the adoption of the new independent auditor's report. Thus, this paper contributes to the literature by presenting empirical evidence of the informational relevance of the content of the new audit report containing KAMs.
\end{abstract}

Keywords: informational relevance, key audit matters, event study.

\footnotetext{
*The authors are grateful to the National Council for Scientific and Technological Development (Conselho Nacional de Desenvolvimento Científico e Tecnológico - CNPq) and to the Research Support Foundation of the State of Espírito Santo (Fundação Estadual de Amparo à Pesquisa do Estado do Espírito Santo - Fapes) for their financial assistance to conduct this research.
} 


\section{INTRODUCTION}

Independent auditors play an important role in reducing informational asymmetry between agents inside and outside companies, especially with regards to the reliability of the accounting information disclosed by entities. Jensen and Meckling (1976) highlight the methods for reducing informational asymmetry between managers and shareholders, these being the independent audit, formal control systems, budgetary constraints, and the establishment of incentives known as asymmetry reduction mechanisms and an alignment of interests between managers and investors. Specifically, one of the aims of the independent audit is to reduce informational asymmetry, minimize conflicts of interest, reduce agency costs, and, consequently, increase the reliability of accounting statements, in order to improve the information in the corporate governance process (Piot, 2001). The main mechanism used for independent auditor communications with market agents is the audit report disclosed with a company's financial statements, since its content can lead to economic agents altering their interpretations regarding company numbers. In this context, understanding how the content of the auditors' report influences the users of accounting information is important for determining whether independent auditors fulfill their role in order for the market to function well.

With the aim of increasing the transparency of the auditing process, improving the reliability of the information contained in accounting reports, and stimulating more solid interactions and communication between the auditor and the entity, the International Auditing and Assurance Standards Board (IAASB) issued, in January of 2015, new requirements regarding the auditor's report. These requirements were the result of pressure from users for the audit report to contain more than just an opinion of consent or not (Defond \& Zhang, 2014).

Aligned with this international pressure, in Brazil the rules were translated and regulated by the Federal Accounting Council (CFC), in June of 2016, with effect for financial statements closed after December $31^{\text {st }}$ of 2016. Among the main alterations caused, there is the inclusion of the key audit matters (KAMs), the inclusion of a description in a separate section in the case of uncertainty regarding the company's operational continuity, and a reallocation of the order of the paragraphs in the audit report, transferring, for example, the opinion section from the end to the beginning of the report (introduced by Brazilian Accounting Standards (NBC TA) 260, 570, 700,
701, 705, and 706 [Federal Accounting Council $\{\mathrm{CFC}\}$, 2016b, 2016c, 2016d, 2016e, 2016a, 2016f]).

The IAASB considers the new audit report to be a highly relevant change, since its aim is to disclose specific aspects of each entity, provide greater transparency to the process for external users, as well as creating an informative link between auditors and investors, highlighting the most important information out of all that disclosed by management to the accounting statement users. In addition, the Public Company Accounting Oversight Board (PCAOB, 2013) commented that KAMs are expected to improve the informative capacity of audit reports by focusing the users' analysis on the most relevant items for decision making.

In this context, the aim of this paper is to investigate whether the KAMs contained in the new audit report of Brazilian listed companies has actually increased the informational relevance for financial statement users who make investment decisions.

The literature has, for quite some time, addressed the discussion regarding the audit report being more communicative with relevant information for users. Some researchers analyze the effect that the extended audit report would have for users. In Poland, for example, an additional report is issued by auditors, containing relevant information for shareholders (Dobija, Cieslak \& Iwuć, 2013).

Some studies argue that this measure would not increase the quality of users' decisions. Vanstraelen, Schelleman, Meuwissen, and Hofmann (2012) state that this report would only provide benefits if it included information that was actually relevant for users. For Defond and Zhang (2014), the desired investor perception is that the audit report contains relevant information with specific characteristics for each company.

In Brazil, the new standard for the report applies to audits of whole sets of financial statements of listed entities. KAMs are issues that, in the auditor's professional judgement, required important attention at the time of carrying out the audit. KAMs are chosen based on topics communicated to those responsible for governance and determined taking into consideration the areas of greatest risk. When describing the KAMs in a report, the auditor is obliged to include the reason for which an issue was considered to be a KAM and how the auditor dealt with the subject [NBC TA 701 (CFC, 2016e)].

Brazil is a good case for analysis, given that the mandatory KAM disclosure came into effect as of the 
2016 fiscal year, allowing for an initial empirical analysis regarding the subject. To exemplify, the 2016 audit report of Natura Cosméticos S.A., a Brazilian publicly-held company, had three KAMs, and one dealt specifically with the company's difficulty in defining an appropriate time for recognizing revenue in accordance with the practices adopted in Brazil. Before, information such as this was discussed between the auditors and management; however, it was not taken to the public. It is thus expected that KAMs will often provide qualitative or quantitative information regarding a particular subject and influence decision making. Therefore, it is conjectured that financial statements accompanied by KAMs should provide the market with more relevant information.

For this study, the event study methodology was used to understand the importance of the effects of disclosing financial statements with an auditor's report containing KAMs on the cumulative abnormal return of the stocks of the companies listed on the Brazilian stock exchange (Brasil, Bolsa, Balcão - B3). Recent studies, such as that of Lennox, Schmidt, and Thompson (2018), use a similar methodology to evaluate the reaction of investors due to the mandatory disclosure of the risks of material misstatements in the financial statements of companies from the United Kingdom.

The sample in this study is composed of Brazilian companies whose stocks are traded on the B3. The data are secondary and were captured in Economatica, on the website of the Brazilian capital market regulator (CVM), and on the companies' investor relations websites. We consider returns from January of 2015 to March of 2018, with the aim of capturing the impacts of the information disclosed relating to 2015,2016, and 2017. The new audit report and disclosure of KAMs became mandatory in 2016.

The results of our investigation indicate that the disclosure of KAMs made the coefficient that indicates the relationship between the variation in the cumulative abnormal returns in the disclosure window for standardized financial statements (SFSs) (which contain KAMs) and the variation in the company's annual abnormal returns had an incremental positive association in relation to the association between the other financial information (mandatory and voluntary) and the variation in returns in the same period. This indicates, even if preliminarily, that the adoption of KAMs has provided some informative content to the Brazilian capital market.

In theoretical terms, this paper contributes to the referential framework regarding the topic, by analyzing a recent adoption scenario with a model that seeks to measure the informational relevance for investors, capturing this result using the abnormal return on the stock. This paper stands out from the studies already carried out on the subject, since it analyzes the market's behavior on receiving particular information. Most of the studies have focused on KAMs and their impacts on the auditor's responsibility, while those that have analyzed their informational relevance have been based on questionnaires mostly applied to a non-investor public (Brown, Majors \& Peecher, 2014; Brasel, Doxey, Grenier \& Reffett, 2016; Christensen, Glover \& Wolfe, 2014). In a recent study, Sirois, Bédard, and Bera (2018) investigated how the adoption of KAMs affects the attention of financial statement users, using an eye-tracking system in an experiment with post-graduate accounting students.

In practical terms, this paper contributes to the capital market regulator (CVM) and to the Institute of Independent Auditors of Brazil (Ibracon) with regards to the regulation and refinement of KAMs in order to improve informational transfer. Finally, this paper contributes to auditors by evaluating the impact of the adoption of KAMs in the Brazilian market. The rest of the paper is organized as follows: section 2 presents the theoretical framework regarding the subject, section 3 discusses the methodology applied, the results are presented in section 4 , and section 5 concludes the paper.

\section{THEORETICAL FRAMEWORK}

\subsection{Informational Asymmetry, Disclosure, and its Benefits}

Lopes and Martins (2005) highlight that "the emergence of the modern corporation with ownership separated from management has created the possibility for conflicts of interest arising between shareholders and managers". The agency relationship consists of signed contracts, with a complex structure that outlines the rights of the involved parties, between the owners of the economic resources (principal) and the managers (agents) hired to control these resources, to whom decision-making power is delegated (Jensen \& Meckling, 1976). Verrecchia (2001) argues that informational asymmetry inhibits investment, thus making the cost of third-party capital more expensive for companies. 
According to Healy and Palepu (2001), the search for disclosure derives from the informational differences and the agency divergences between managers and investors, and some evidence leads to the belief that there is an opposing relationship between disclosure and asymmetry (Brown \& Hillegeist, 2007; Heflin, Shaw \& Wild, 2005).

According to Souza (1995), disclosure consists of making a company's quantitative or qualitative information public to the market, by requirement or voluntarily, through any means of communication, whether formal or informal. This is so important that some studies relate stock returns with the level of company disclosure (Ball \& Shivakumar, 2008; Beyer, Cohen, Lys \& Walther, 2010; Locatelli, 2016; Malaquias \& Lemes, 2015; Takamatsu, Lamounier \& Colauto, 2008).

With the aim of minimizing asymmetry, Brazilian publicly-held companies have to disclose all information that is considered relevant through immediate communication to the CVM, thus leading to this information being filed in the institution's public database. The necessary disclosure of situations that are considered relevant aims to prevent undue privileged access to information (Reiter \& Procianoy, 2013).

According to art. 2 of CVM Instruction $\mathrm{n}$. 358/2002 (Comissão de Valores Mobiliários [CVM], 2002), the following is considered a relevant act or fact:

any decision of the controlling shareholder, deliberation in a general meeting or by the management bodies of a publiclyheld company, or any act or fact of a political-administrative, technical, business, or economic-financial nature that may influence the quotation price of the company's securities or investors' decisions.

Recently, Costa, Galdi, Motoki, and Sanchez (2016) demonstrated that companies that did not disclose the remuneration of their executives had a higher information asymmetry cost in the Brazilian market, indicated by a greater bid-ask spread, in relation to those that did disclose. In this context, the CVM establishes that companies have to disclose annual and quarterly financial statements together with their independent auditor's report.

\subsubsection{New audit report and independent audit}

Audits are valued for their ability to provide an independent guarantee of the credibility of accounting information and they are of the upmost importance to minimize the agency theory. Yet, the waves of accounting irregularities have led to questions regarding the independence of auditors (Ghosh \& Moon, 2005).

These questions have been raised due to the bankruptcies of companies that were renowned in the market, such as Enron Corporation (Porter \& Gowthorpe, 2004), which filed for bankruptcy after adjusting its accounts, which received an unmodified opinion from its auditor, Arthur Andersen LLP. Similar results have been noted in companies such as WorldCom, Global Crossing Limited, and Rank Xerox in the United States of America. In Italy, Parmalat S.p.A. entered into bankruptcy in 2003, after involvement in an accounting scandal (Demaki, 2011).

Even with the irregularities found, independent auditors are considered the "guardians" of the public securities markets and, therefore, auditor independence is needed due to the fact that the impact is directly linked to the quality of the audit (Ghosh \& Moon, 2005). The four dimensions that enable the impact of the auditor's independence over the quality of the audit to be evaluated are: the importance of the client, non-auditing services, the auditor's tenure, and the client's relationship with the auditing firms (Tepalagul \& Lin, 2015).

Defond and Zhang (2014) state that the growing potential for corporate transactions and the increase in the complexity of accounting judgements that involve a company's day-to-day constantly corroborate the new positioning of auditing firms; however, a new positioning of auditing firms is not enough, and reflection on the informational relevance of the audit report is also required.

The form, content, and value to investors of the audit report have been quite widely criticized (Carson et al., 2013). Auditors have been criticized for using very standardized language, for not explaining how they have reached the opinion provided in the audit report, and for not sufficiently communicating with the people whose interest they should protect - shareholders and potential investors (Cordoş \& Fülöp, 2015).

For Defond and Zhang (2014), audits cannot be merely seen as certification that there are no relevant errors or misstatements in the accounting statements, but also that the financial statements economically reflect the company's situation.

In light of this, in 2013, via a public consultation with the users of audit reports, the IAASB verified a series of requests to alter the model that was being used. "In general, these consultations revealed the desire for accounting statements to be clearer and more transparent, as well for the audit report to be more specific and less generic" (Ibracon, 2013).

Longo (2017) notes that financial information users sought significant alterations in order to cover additional aspects, going beyond a mere opinion regarding the accounting and legal standards and structural questions, making clear how these aspects influence the entity.

Therefore, the main item included in the IAASB's final proposal is the disclosure of key audit matters 
(KAMs), which aim to disclose a paragraph with the most significant subjects, including the reason for which the auditor considered each one to be a KAM and what treatment was given to the point during the course of the audit work [NBC TA 701 (CFC, 2016e)]. The new standards were adapted and regulated by the CFC in 2016, with effect for accounting statements closed after December $31^{\text {st }}$ of 2016 . The auditor's obligation to communicate KAMs was introduced by NBC TA 701, of June $17^{\text {th }}$ of 2016 (CFC, 2016e), issued by the CFC. In addition, NBC TA 700, of June $17^{\text {th }}$ of 2016 (CFC, 2016d), introduces, in paragraph 30 , the need to communicate KAMs in the auditor's report in the case of audits of complex sets of accounting statements for general purposes of listed entities. A study conducted in Brazil relating to the first year of adoption demonstrates that all financial institutions successfully carried out all the alterations foreseen in NBC TA 701 (CFC, 2016e; Silva \& Dantas, 2018).

Although this additional disclosure is expected to increase the informational content of the audit report for investors (Christensen et al., 2014), various interest groups have expressed their concern that KAMs also increase the responsibility risks of the auditing team (Deloitte, 2013).

According to Cordoş and Fülöp (2015), KAMs strengthen the theory of inspired confidence because they provide users with relevant information for decision making. Gimbar, Hasen, and Ozlanski (2016) argue that these changes have a significant impact in terms of increasing the auditor's responsibility and should lead auditors to increase the value of their auditing work, since they will have to expand the auditing procedures for risk minimization. Brown et al. (2014) state that the auditor's responsibility is reduced when a disclosed KAM is related to a topic in which fraud had been found at some previous moment.

In France, since 2003 there have been audit explanations similar to KAMs. Bédard, Gonthier-Besacier and Schatt (2014) state that the disclosure of such information has more symbolic than informational value.

Christensen et al. (2014) state that investors who receive a KAM paragraph are more likely to change their investment decisions than those who receive a standard audit report. It was also found that the paragraph with the resolution given by the auditor influences the decisions of an investor differently from a KAM without the auditor's treatments. According to Köhler, Ratzinger-Sakel, and Theis (2016), the KAM section for non-professional investors has no communicative value, which is explained by the difficulty of processing the information conveyed.

A company's disclosure level can affect the trading value and volume of its stocks. The content of the audit report indirectly increases or decreases the will of investors to invest (Elliott, Fanning \& Peecher, 2016). Based on this assumption, together with the KAM section included in the audit report, the following research hypothesis is built:

H1: the disclosure of KAMs in financial statements has informational content and is relevant in investors' judgements, thus causing an increase in the association between the accounting information and the return on the stocks of publicly-held corporations.

\section{METHODOLOGY}

\subsection{Structure of the Study}

With the aim of evaluating the impact of the informational relevance of KAMs on the perception of the stock market in Brazil, a quantitative study was employed, gathering data on all the stocks listed as active on the B3 and the dates of all the disclosure events, whether mandatory or voluntary, as listed in Table 1 . The data used are secondary and were collected from the Economatica database and the CVM website for the period between 01/01/2015 and 03/29/2018.

To capture the impact of the informational relevance of the KAMs over the stock returns of the companies listed on the B3, the event study methodology was used, which consists of evaluating how the information influences the market at a particular moment. Thus, the sum of the daily abnormal returns of each company on the days that form part of the event window was used. The event window considered was one day before the event, the day of the event, and one day after the event, as according to Beyer et al. (2010).

Disclosure theory segregates disclosed information into basically two groups: mandatory and voluntary. Mandatory disclosures are regulated by a rule that obliges the company to disclose certain facts to the market, for example: accounting statements and a change of directors. Voluntary disclosures, in turn, is information that the company judges necessary to disclose, but that is not required by any rule. To apply the statistical model, the event of disclosure of the annual SFSs and of the quarterly 
information (QI) was separated from the other mandatory disclosures.

The CVM makes available the information disclosed by publicly-held companies. The CVM itself classifies this information by categories on its website. To apply the statistical model, an analysis was carried out of each one of the categories and then a classification was made between mandatory disclosure and voluntary disclosure, in accordance with the legislation in effect. Table 1 presents the classification of those categories used in this study.

Table 1

Category classification

\begin{tabular}{|c|c|}
\hline Category & Type \\
\hline Assembly & Mandatory \\
\hline Board meeting & Mandatory \\
\hline Bylaw & Mandatory \\
\hline Code of conduct & Mandatory \\
\hline Communication regarding transaction between related parties & Mandatory \\
\hline Communication to the market & Partial \\
\hline Corporate groupings agreement & Mandatory \\
\hline Corporate events calendar & Voluntary \\
\hline Credit securitization and amendments term & Mandatory \\
\hline Debenture deeds and amendments & Mandatory \\
\hline Dividends policy & Mandatory \\
\hline Economic-financial data & Mandatory \\
\hline Information on companies in bankruptcy & Mandatory \\
\hline Information on companies in judicial and extrajudicial recovery & Mandatory \\
\hline Information on companies in liquidation & Mandatory \\
\hline $\begin{array}{l}\text { Information on shareholder agreements foreseen in } \\
\text { art. } 30 \text { (XIX) of CVM Instruction n. 480/2009 (CVM, 2009) }\end{array}$ & Mandatory \\
\hline Information provided to foreign exchanges & Voluntary \\
\hline Notice to debenture holders & Voluntary \\
\hline Notice to shareholders & Voluntary \\
\hline Policy for disclosure of relevant acts or facts & Mandatory \\
\hline Policy for trading company shares & Mandatory \\
\hline Policy for transactions between related parties & Mandatory \\
\hline Public offering documents & Mandatory \\
\hline Registration details of incentivized companies & Mandatory \\
\hline Relevant fact & Mandatory \\
\hline Resolution issued by the Central Bank & Mandatory \\
\hline Risk management policy & Voluntary \\
\hline Shareholders agreement & Mandatory \\
\hline Statutory internal regulation of the auditing committee & Mandatory \\
\hline Stock-based compensation plan & Mandatory \\
\hline Stock-based compensation plan (except options plan) & Mandatory \\
\hline Sustainability report & Voluntary \\
\hline TB - Public takeover bid & Mandatory \\
\hline $\begin{array}{l}\text { Traded and held securities } \\
\text { (art. } 11 \text { of CVM Instruction n. 358/2002) (CVM, 2002) }\end{array}$ & Mandatory \\
\hline Unsponsored BDR - Operational description of the program & Voluntary \\
\hline
\end{tabular}

$B D R=$ Brazilian depositary receipt $; B=$ takeover bid.

Source: Elaborated by the authors. 
The "communication to the market" category has been classified as partial, since there are information types in this category that can be classified as mandatory or voluntary. Therefore, each one of the information types of these categories was analyzed, manually classifying them for statistical modeling purposes. In the "economicfinancial data" category, the information relating to the disclosure of the SFS was separated from that of the QI. Table 2 presents the set of information that composes the disclosure of the SFS and of the QI.

Table 2

Quarterly information (QI) vs. standardized financial statements (SFSS)

\begin{tabular}{lll}
\hline Information disclosed & QI & SFSs \\
\hline Balance sheet & Yes & Yes \\
\hline Cash flow statement & Yes & Yes \\
\hline Comprehensive income statement & Yes & Yes \\
\hline Income statement & Yes & Yes \\
\hline Independent auditors' report with KAMs & No & Yes \\
\hline Statement of added value & Yes & Yes \\
\hline Statement of changes in net equity & Yes & Yes \\
\hline
\end{tabular}

KAMs = key audit matters.

Source: Elaborated by the authors.

Thus, from Table 2, it is noted that the main information that differentiates the QI from the SFS is the independent auditor's report. For the QI, the auditing work is limited and obeys NBC CTA 18, of July $26^{\text {th }}$ of 2013 (CFC, 2013) (disclosure of the independent auditor's report and auditing procedures required in the case of resubmitting accounting statements or interim information), and the main differences are the less comprehensive review and the way the report is presented. The audit report disclosed in the set of SFSs presents the paragraph with the KAMs observed while carrying out the work, this paragraph not being disclosed in the QI.

Considering that the obligation to include KAMs came into effect in 2017 for the fiscal year ending in 2016, the model that captures the variations will be used for a comparison between the returns relating to the information disclosed regarding 2015 and 2016. For this, the statistical model described in equation 1 is used, based on Ball and Shivakumar (2008) and Beyer et al. (2010).

$$
\begin{gathered}
\Delta \operatorname{Car}_{\mathrm{i}, \mathrm{t}}^{\mathrm{YEAR}}=\beta_{0}+\beta_{1} \Delta \operatorname{Car}_{\mathrm{i}, \mathrm{t0}}^{\mathrm{SFS}}+\beta_{2} \Delta \operatorname{Car}_{\mathrm{i}, \mathrm{t} 1}^{\mathrm{QI} \mathrm{Q} 1}+\beta_{3} \Delta \operatorname{Car}_{\mathrm{i}, \mathrm{t} 2}^{\mathrm{QI} \mathrm{Q} 2}+\beta_{4} \Delta \operatorname{Car}_{\mathrm{i}, \mathrm{t} 3}^{\mathrm{QI} \mathrm{Q} 3}+ \\
\beta_{5} \Delta \operatorname{Car}_{i}^{\mathrm{OD}}+\beta_{6} \Delta \operatorname{Car}_{i}^{\mathrm{VD}}+\Sigma \beta_{\mathrm{m}} \Delta_{\text {Controls }}\left(\mathrm{Roa}, \operatorname{Surp}_{\mathrm{Ear}}, \mathrm{Mv}\right)_{i, t}+\varepsilon_{i, t}
\end{gathered}
$$

in which the coefficient $\beta_{1}$ indicates the effect for the disclosure of the set of SFSs and includes the independent auditor's report with the KAMs, $\beta_{2}$ indicates the effect for the disclosure of the information from the first quarter, $\beta_{3}$ the effect for the disclosure of the information from the second quarter, $\beta_{4}$ the effect for the disclosure of the information from the third quarter, $\beta_{5}$ the effect for the disclosure of the other mandatory information, and $\beta_{6}$ the effect for the disclosure of the other voluntary information. $\beta_{1}$ is expected to present a statistically greater coefficient than that of the others. This is because, if the disclosure of the KAMs is relevant, it should increase the association between the cumulative abnormal returns in the event window of their disclosure and the abnormal returns of the company's stocks. This model aims to analyze the variation occurring between the periods for the cumulative abnormal return of the different events. The intuition is that of the total cumulative abnormal return of year $t$ relating to the information disclosed on date $t$, each one of the disclosure events (SFS, QI, mandatory disclosure, and voluntary disclosure) will show a positive association with the $\mathrm{Car}_{\mathrm{i}, \mathrm{t}}^{\mathrm{YEAR}}$, and that with the introduction of KAMs, this association will be more relevant for the disclosure of the SFSs, it therefore being expected that coefficient $\beta_{1}>\beta_{n}>0$. Table 3 presents the description of each variation of the equation. 
Table 3

Description of the variables

\begin{tabular}{|c|c|}
\hline Variables & Description \\
\hline$\Delta \operatorname{Car}_{\mathrm{i}, \mathrm{t}}^{\mathrm{YEAR}}$ & Variation in the annual abnormal return between the periods $(2017,2016$, and 2015) \\
\hline$\Delta \mathrm{Car}_{\mathrm{i}, \mathrm{t} 0}^{\mathrm{SFS}}$ & $\begin{array}{l}\text { Variation in the annual abnormal return between the periods }(2017,2016 \text {, and } 2015) \text { in the disclosure window for the } \\
\text { standardized financial statement on date to }\end{array}$ \\
\hline$\Delta \mathrm{Car}_{\mathrm{i}, t 1}^{\mathrm{QI} Q 1}$ & $\begin{array}{l}\text { Variation in the annual abnormal return between the periods }(2017,2016 \text {, and } 2015) \text { in the window in which there was } \\
\text { disclosure of the QI relating to the first quarter on date } t 1\end{array}$ \\
\hline$\Delta \mathrm{Car}_{\mathrm{i}, \mathrm{t2}}^{\mathrm{OI} \mathrm{Q} 2}$ & $\begin{array}{l}\text { Variation in the annual abnormal return between the periods }(2017,2016 \text {, and } 2015) \text { in the window in which there was } \\
\text { disclosure of the QI relating to the second quarter on date } t 2\end{array}$ \\
\hline$\Delta \mathrm{Car}_{\mathrm{i}, \mathrm{Q} 3}^{\mathrm{QI} \mathrm{Q3}}$ & $\begin{array}{l}\text { Variation in the annual abnormal return between the periods }(2017,2016 \text {, and } 2015) \text { in the window in which there was } \\
\text { disclosure of the QI relating to the third quarter on date } t 3\end{array}$ \\
\hline$\triangle \mathrm{Car}_{\mathrm{i}}^{\mathrm{OD}}$ & $\begin{array}{l}\text { Variation in the abnormal return in the window in which there was disclosure of the mandatory information, as according } \\
\text { to the classification established in Table } 1\end{array}$ \\
\hline$\Delta \mathrm{Car}_{i}^{\mathrm{VD}}$ & $\begin{array}{l}\text { Variation in the abnormal return in the window in which there was disclosure of the voluntary information, as according } \\
\text { to the classification established in Table } 1\end{array}$ \\
\hline$\Delta$ Roa & Variation in the return on assets between the periods $(2017,2016$, and 2015) \\
\hline$\triangle$ Surp_ear & $\begin{array}{l}\text { Variation in the earnings surprise between the periods }(2017,2016 \text {, and 2015). The earnings forecast presented in the } \\
\text { previous period in comparison with the earnings of the current period was considered }\end{array}$ \\
\hline$\Delta \ln \_\mathrm{mv}$ & Variation in the company's market value between the periods $(2017,2016$, and 2015) \\
\hline
\end{tabular}

QI = quarterly information.

Source: Elaborated by the authors.

\subsection{Cumulative Abnormal Returns Calculation}

For the abnormal returns, the market-adjusted return statistical model was considered; they were calculated by the difference between the observed return on the asset and the market return in the same period:

$$
\mathrm{A}_{\mathrm{it}}=\mathrm{R}_{\mathrm{it}}-\mathrm{R}_{\mathrm{mt}}
$$

in which $\mathrm{A}_{\mathrm{it}}$ is the abnormal return on a stock in the period, $\mathrm{R}_{\mathrm{it}}$ is the verified return on a stock in the same period, and $\mathrm{R}_{\mathrm{mt}}$ is the return on the whole portfolio distributed via volume and trading of the asset in the same period.

The return on the stocks of all the companies listed on the B3 was calculated for all the days of the base-period by equation 3 :

$$
R_{i t}=\frac{P_{t}-P_{t-1}}{P_{t-1}}
$$

in which $\mathrm{R}_{\mathrm{it}}$ is the rate of return on stock $i$ in period $t$, considering as the period all the days on which the stock exchange was open in 2015, 2016, and 2017, and in 2018 up to March $29^{\text {th }}, \mathrm{P}_{\mathrm{t}}$ is the closing price of stock $i$ on date $t$, and $\mathrm{P}_{\mathrm{t}-1}$ is the closing price of the stock on date $\mathrm{t}-1$.

Next, the average market return was calculated by the sum of the return on the whole portfolio of assets weighted by its respective trading volume on date $t$ in reais $\mathrm{w}_{\mathrm{it}}$ over the total market value on date $t$ in reais $\mathrm{R}_{\mathrm{t}}$, as according to equation 4 .

$$
\mathrm{Rm}_{\mathrm{it}}=\sum_{\mathrm{t}=1}^{3} \mathrm{R}_{\mathrm{t}} \cdot \mathrm{w}_{\mathrm{it}}
$$

To accumulate the abnormal returns on the stocks on the day of the event window, the cumulative abnormal return (CAR) was used, which is similar to that used by Beyer et al. (2010):

$$
\operatorname{CAR}_{\mathrm{i}}\left(\mathrm{t}_{1}, \mathrm{t}_{3}\right)=\sum_{\mathrm{t}=1}^{\mathrm{t} 3} \mathrm{~A}_{\mathrm{it}}
$$

in which $\mathrm{CAR}_{\mathrm{i}}$ is the cumulative return on the asset, $t_{1}$ is the first day of the event window, $t_{3}$ is the last day of the event window, and $\mathrm{A}_{\mathrm{it}}$ is the abnormal return on a stock in the period.

\subsection{Annual CAR Calculation}

Given the statistical model, the $\mathrm{Car}_{i, t}^{\text {YEAR }}$ variable measurement represents the accumulation of abnormal returns occurring in the whole of year $t$ for company $i$. Yet, as each company discloses its SFSs relating to the previous period on a different date, which by rule must occur by March $31^{\text {st }}$ of the subsequent fiscal year, the adjustment was made to contemplate this. To adjust the effect of the cumulative abnormal returns of the SFS window from other periods, the following equation was considered:

$$
\mathrm{Car}_{i, t}^{\text {YEAR }}=\mathrm{Car}_{\mathrm{i}, \mathrm{t}}^{\text {year with no adjustemnt }}-\mathrm{Car}_{\mathrm{i}, \mathrm{t}}^{\mathrm{SFS}}+\mathrm{Car}_{\mathrm{i}, \mathrm{t}+1}^{\mathrm{SFS}} \mathbf{6}
$$

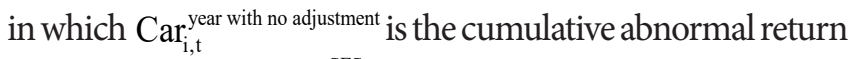
on stock $i$ in year $t, \mathrm{Car}_{\mathrm{i}, \mathrm{t}}^{\mathrm{SFS}}$ is the cumulative abnormal return on stock $i$ in the disclosure window for the SFS from the previous year disclosed in year $t$, and $\mathrm{Car}_{\mathrm{i}, \mathrm{t}+1}^{\mathrm{FSS}}$ is the cumulative 
abnormal return on stock $i$ in the disclosure window for the SFS from year $t$ disclosed in year $t+1$.

For a better understanding, the expressions used yearto-year were:

$$
\begin{aligned}
& \operatorname{Car}_{i, 2015}{ }^{\text {YEAR }}: \\
& \text { Car }_{i, 2015}^{\text {year with no adjustment }} \text { (abnormal return between } \\
& 01 / 01 / 2015 \text { and } 12 / 31 / 2015 \text { ) }
\end{aligned}
$$

(-) $\mathrm{Car}_{i, 2015}^{\mathrm{SFS}}$ (abnormal return of the window in 2015 , in which there was disclosure of the financial statements from 2014)

(+) $\mathrm{Car}_{i, 2016}^{\mathrm{SFS}}$ (abnormal return of the window in 2016, in which there was disclosure of the financial statements from 2015)

$\operatorname{Car}_{i, 2016}{ }^{\text {YEAR }}$ :

$\mathrm{Car}_{\mathrm{i}, 2016}^{\text {year with no adjustment }}$ (abnormal return between $01 / 01 / 2016$ and $12 / 31 / 2016$ )

(-) $\mathrm{Car}_{i, 2016}^{\mathrm{SFS}}$ (abnormal return of the window in 2016, in which there was disclosure of the financial statements from 2015)

(+) $\mathrm{Car}_{i, 2017}^{\mathrm{SFS}}$ (abnormal return of the window in 2017 , in which there was disclosure of the financial statements from 2016)

$\operatorname{Car}_{i, 2017}{ }^{\text {YEAR }}$ :

$\mathrm{Car}_{\mathrm{i}, 2017}^{\text {year with no adjustment }}$ (abnormal return between $01 / 01 / 2017$ and $12 / 31 / 2017$ )

(-) $\mathrm{Car}_{i, 2017}^{\mathrm{SFS}}$ (abnormal return of the window in 2017, in which there was disclosure of the financial statements from 2016)

(+) $\mathrm{Car}_{i, 2018}^{\mathrm{SFS}}$ (abnormal return of the window in 2018 , in which there was disclosure of the financial statements from 2017)

\subsubsection{SFS CAR Calculation}

To calculate the cumulative returns around the date of disclosure of the SFSs, their disclosure date was taken for all the publicly-held companies with stocks listed on the stock exchange. For the dates that for some reason did not fall on a working day, the next working day was always considered, which is when the market reacts to this information. Based on each company's SFS disclosure date, the CAR of the event window was calculated, this being one day before and one day after the disclosure date.

\subsubsection{QI CAR Calculation}

For each company, the disclosure date was taken of the three QI reports (first, second, and third quarters) relating to the period. The fourth quarter was not considered as it is already contemplated in the annual disclosure (SFS). For the dates that for some reason did not fall on a working day, the next working day was always considered, which is when the market reacts to this information. Based on the QI disclosure date, the CAR of the event window was calculated for each one of the quarters.

\subsubsection{Mandatory CAR Calculation}

Based on the classification of the disclosure categories, all the dates during the year on which the companies disclosed some mandatory information to the market were taken. For the dates that for some reason did not fall on working days, the next working day was always considered, which is when the market reacts to this information.

Each company has a set of mandatory disclosures that it must always disclose if that event occurs. For example, acts of extraordinary general meetings must be disclosed, but there is no specific periodicity. Thus, it is considered that these events can occur on non-specific dates and the returns around these events are calculated. In the case of the occurrence of more than one event, the returns around each one of the events are added up for consideration of the cumulative return. Therefore, based on the dates of disclosure of the mandatory information, the CAR of the event window for each disclosure was calculated and, then, all the CARs of these windows were added up to produce the $\mathrm{Car}_{0}^{\mathrm{OD}}$ variable.

\subsubsection{Voluntary CAR Calculation}

Based on the classification of the disclosure categories, all the days during the year on which the companies disclosed some voluntary information to the market were taken. For the dates that for some reason did not fall on a working day, the next working day was always considered, which is when the market reacts to this information. Based on the dates of disclosure of the voluntary information, the CAR of the event window for each disclosure was calculated and, then, all the CARs of the windows were added up to produce the $\mathrm{Car}_{0}^{\mathrm{VD}}$ variable.

\subsection{Data Treatment}

According to the proposed model, the return will be calculated based on the stocks and controlled by their trading code. Initially, the database retrieved from Economatica was composed of 753 companies, which add up to 1,271 stocks; after ignoring the companies that appear as "canceled" in the Economatica record, 577 stocks remain. 
Table 4

Sampling base

\begin{tabular}{ll}
\hline Description & Stocks \\
\hline Companies listed on the Brasil, Bolsa, Balcão (B3) & 1,271 \\
\hline Canceled companies & 694 \\
\hline Total database & 577 \\
\hline Exclusion of the company classes with the least movement & 263 \\
\hline Database for the analysis & 314 \\
\hline
\end{tabular}

Source: Elaborated by the authors.

For the companies with more than one stock listed on the stock exchange, the study concentrated on the most liquid stocks in the market.

For each stock, the daily closing price of the respective stock was taken from Economatica and, subsequently, the value of the return on the stock was calculated for the respective date. In the case of companies whose stock is not quoted every day, this was not considered for the purposes of return on that date.

Table 5

Data cleansing

\begin{tabular}{|c|c|c|c|}
\hline Description & 2015 & 2016 & 2017 \\
\hline Database for analysis & 314 & 314 & 314 \\
\hline Stocks that were not traded in the SFS or QI disclosure window & 69 & 76 & 76 \\
\hline Stocks that were not traded in the whole period & 30 & 27 & 32 \\
\hline Companies with no market value & 49 & 47 & 56 \\
\hline Companies that did not disclose earnings in one of the periods used to calculate the earnings surprise variable & 17 & 17 & 34 \\
\hline $\begin{array}{l}\text { Companies that did not present one of the variables in one of the periods, making it impossible to calculate the } \\
\text { variation in the variables }\end{array}$ & 18 & 16 & 22 \\
\hline Observations & 131 & 131 & 94 \\
\hline
\end{tabular}

SFS = standardized financial statement; $Q I=$ quarterly information

Source: Elaborated by the authors.

\subsection{Control Variables}

Given the fragility of the proposed model, since the audit report is disclosed with various different pieces of financial and accounting information and even future management projections, the following controls were considered to eliminate and minimize the possible distortion effects.

- ROA: the return on assets obtained by the following equation:

$$
\mathrm{ROA}=\text { Net Earnings }_{\mathrm{t}} / \text { Total }_{\text {Assets }} \mathrm{t}_{\mathrm{1}}
$$

$\triangle \mathrm{ROA}$ is the variation in the return on assets of the company from one year in relation to another.

- SURP_EAR: earnings surprise (SURP_EAR) was considered as the difference between the current period's earnings in relation to the earnings from the same period of the previous year divided by the absolute value of the current period's earnings. Thus, the surprise was measured according to the equation:

$$
\text { Surprise }=\operatorname{EAR}_{0}^{\text {real }}-\mathrm{EAR}_{0}^{\mathrm{t}-1} /\left|\mathrm{EAR}_{0}^{\text {real }}\right|
$$

in which $\mathrm{EAR}_{0}^{\text {real }}$ is the actual net earnings in the period and $\mathrm{EAR}_{0}^{\mathrm{t}-1}$ is the actual net earnings in the previous period.

- $\Delta$ Ear_dummy: represents a dummy variable that is 1 if the company had net earnings and 0 otherwise.

- MV: is the market value of the company's net equity on the closing date of the fiscal year. The value is obtained via the following equation:

$$
\begin{gathered}
\text { MV = total stocks * unadjusted prices } \\
\text { for annual proceeds }
\end{gathered}
$$

For companies with more than one class of stock, the formula is:

$$
\begin{gathered}
\mathrm{MV}=\text { price class } \mathrm{A}^{*} \text { quantity class } \mathrm{A} \\
\text { + price class } \mathrm{B}{ }^{*} \text { quantity class } \mathrm{B}
\end{gathered}
$$

- The $\Delta \ln M V$ variable represents the difference in the Naperian logarithm of the company's market value in period $t$ in relation to the Naperian logarithm of the company's market value in period $t-1$. Specifically, we have:

$$
\Delta \ln M V=\ln \left(m v_{t}\right)-\ln \left(m v_{t-1}\right)
$$




\section{RESULTS}

\subsection{Descriptive Statistics}

Table 6 presents the descriptive statistics of the variables used in the regression. Under analysis, it is observed that the means of the variation variables of the CAR are greater than the medians, suggesting an asymmetric distribution of the variations in the returns.

Table 6

Descriptive statistic of the variables

\begin{tabular}{|c|c|c|c|c|c|c|}
\hline Variable & Obs. & Mean & Median & Stand. deviation & $1^{\text {st }}$ Quartile & $3^{\text {rd }}$ Quartile \\
\hline$\Delta \operatorname{Car}_{i, t}^{\mathrm{YEAR}}(\%)$ & 225 & 34.83 & 28.60 & 88.65 & -7.01 & 70.42 \\
\hline$\Delta \operatorname{Car}_{i, t}^{\mathrm{SPS}}(\%)$ & 225 & -0.53 & -0.65 & 8.64 & -5.76 & 3.84 \\
\hline$\Delta \mathrm{Car}^{\mathrm{VD}}(\%)$ & 225 & 6.15 & 3.19 & 37.52 & -11.23 & 20.14 \\
\hline$\Delta \mathrm{Car}^{\mathrm{OD}}(\%)$ & 225 & 15.95 & 8.82 & 73.76 & -17.44 & 43.82 \\
\hline$\Delta \operatorname{Car}_{i, t}^{\mathrm{OlQl}}(\%)$ & 225 & 0.61 & 0.37 & 9.26 & -3.96 & 5.10 \\
\hline$\Delta \mathrm{Car}_{\mathrm{i}, \mathrm{t}}^{\mathrm{OI} \mathrm{Q}^{2}}(\%)$ & 225 & 1.43 & 0.79 & 8.64 & -3.42 & 6.55 \\
\hline$\Delta \mathrm{Car}_{\mathrm{i}, \mathrm{t}}^{\mathrm{OI} \mathrm{Q} 3}(\%)$ & 225 & -1.36 & -0.06 & 9.24 & -6.46 & 4.17 \\
\hline$\Delta$ Surp_ear $(\%)$ & 225 & 0.96 & 0.05 & 28.69 & -0.63 & 1.49 \\
\hline$\Delta$ Ear_dummy & 225 & -0.03 & 0.00 & 0.49 & 0.00 & 0.00 \\
\hline$\Delta$ roa $(\%)$ & 225 & 0.24 & -0.10 & 14.86 & -2.60 & 2.00 \\
\hline$\Delta \mathrm{ln} \_\mathrm{Mv}$ & 225 & 0.30 & 0.26 & 0.46 & 0.06 & 0.51 \\
\hline
\end{tabular}

Note: The variables refer to company $i$, year $t$, and are expressed in percentages, with the exception of the $\Delta$ Ear_dummy and

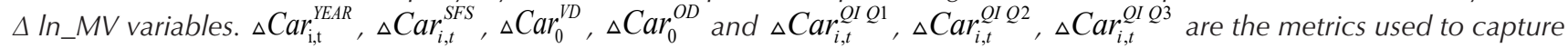
the variation in the abnormal return of the windows between the periods of the events. $\Delta$ Car, ${ }_{i, t}^{Y E A R}$ is understood as the variation in the annual abnormal return; $\triangle \mathrm{Car}_{i, t}^{S F S}$ is the variation in the abnormal return on stock $i$ in the disclosure window of the annual standardized financial statement; $\triangle \mathrm{Car} r_{0}^{V D}$ is the variation in the abnormal returns of the windows in which there was voluntary disclosure of information; $\triangle \mathrm{Car}_{0}{ }^{O D}$ is the variation in the abnormal returns of the windows in which there was mandatory disclosure; $\triangle \mathrm{Car}_{i, t}^{\mathrm{OI}} \mathrm{Q1}$ is the variation in the abnormal return of the disclosure window for the quarterly information (QI) from the first quarter; $\triangle \mathrm{Car}_{i, t}^{\mathrm{OI} Q^{2}}$ is the variation in the abnormal return of the disclosure window for the quarterly information (QI) from the second quarter; $\triangle \mathrm{Car}_{i, t}^{\mathrm{OI}} \mathrm{O}_{3}$ is the variation in the abnormal return of the disclosure window for the quarterly information (QI) from the third quarter; $\Delta$ Surp_ear is the variation in the earnings surprise; $\Delta$ Ear_dummy is a dummy variable that is 1 if the company had net earnings and 0 otherwise; $\triangle R O A$ is the variation in the return on assets; $\triangle I n \_M V$ is the variation in the Naperian logarithm of the company's market value. All the variations were calculated with relation to the same period of the previous year. The Winsor method was used to minimize the effect of the outliers on the ROA variable $(2.5 \%$ in each tail of the distribution).

Source: Elaborated by the authors.

In addition, the correlation was evaluated between the variables used in this study in order to identify possible signs of multicollinearity. No relationships were found that could indicate high multicollinearity between the explanatory variables of this study. Table 7 presents the results. 
Table 7

Correlation analysis

\begin{tabular}{|c|c|c|c|c|c|c|c|c|c|c|c|}
\hline & $\triangle \operatorname{Car}^{\mathrm{YEAR}}$ & $\triangle \mathrm{Car}^{\mathrm{SFS}}$ & $\triangle \mathrm{Car}^{\mathrm{VD}}$ & $\triangle$ Car $^{\mathrm{OD}}$ & $\triangle \mathrm{Car}^{\mathrm{Q} \mathrm{QQ1}}$ & $\triangle \mathrm{Car}^{\mathrm{QIQ2}}$ & $\triangle \mathrm{Car}^{\mathrm{QIQ} \mathrm{3}}$ & $\Delta$ Surp_ear & $\Delta$ Ear_dummy & $\Delta$ roa & $\Delta \mathrm{ln} \_\mathrm{MV}$ \\
\hline$\triangle \operatorname{Car}^{\mathrm{YEAR}}$ & 1.000 & & & & & & & & & & \\
\hline$\triangle \mathrm{Car}^{\mathrm{SFS}}$ & 0.292 & 1.000 & & & & & & & & & \\
\hline$\triangle \mathrm{Car}^{\mathrm{VD}}$ & 0.307 & -0.062 & 1.000 & & & & & & & & \\
\hline$\triangle \mathrm{Car}^{\mathrm{OD}}$ & 0.632 & 0.082 & 0.443 & 1.000 & & & & & & & \\
\hline$\triangle$ Car $^{\mathrm{QIQ1}}$ & 0.316 & 0.094 & 0.076 & 0.099 & 1.000 & & & & & & \\
\hline$\triangle \mathrm{Car}^{\mathrm{Q} \mathrm{IQ2}}$ & 0.378 & 0.044 & 0.100 & 0.317 & 0.194 & 1.000 & & & & & \\
\hline$\triangle \mathrm{Car}^{\mathrm{Q} \longmapsto 3}$ & 0.087 & 0.088 & 0.131 & 0.085 & 0.031 & -0.029 & 1.000 & & & & \\
\hline$\Delta$ Surp_ear & 0.224 & 0.111 & 0.033 & 0.092 & 0.149 & 0.129 & -0.051 & 1.000 & & & \\
\hline $\begin{array}{l}\Delta \text { Ear_}_{-} \\
\text {dummy }\end{array}$ & 0.043 & -0.033 & 0.131 & 0.032 & 0.021 & -0.011 & -0.020 & 0.122 & 1.000 & & \\
\hline$\Delta$ roa & 0.164 & 0.087 & 0.197 & 0.225 & -0.007 & 0.051 & 0.160 & 0.108 & 0.413 & 1.000 & \\
\hline$\Delta \mathrm{ln} \_\mathrm{MV}$ & 0.314 & -0.101 & 0.293 & 0.259 & -0.007 & 0.037 & 0.126 & 0.068 & 0.134 & 0.118 & 1.000 \\
\hline
\end{tabular}

Note: The variables refer to company $i$, year $t$, and are expressed in percentages, with the exception of the $\Delta$ Ear_dummy and

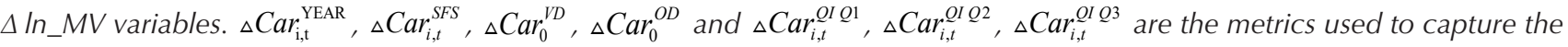
variation in the abnormal return of the windows between the periods of the events. ${ }_{\Delta}$ Car $_{\mathrm{i}, \mathrm{t}}^{\mathrm{YEAR}}$ is understood as the variation in the annual abnormal return; ${ }_{\Delta} \mathrm{Car}_{i, t}^{S F S}$ is the variation in the abnormal return on stock $i$ in the disclosure window of the annual standardized financial statement; $\Delta \mathrm{Car}_{0}^{V D}$ is the variation in the abnormal returns of the windows in which there was voluntary disclosure of information; $\triangle \mathrm{Car}_{0}{ }^{O D}$ is the variation in the abnormal returns of the windows in which there was mandatory disclosure; $\triangle \mathrm{Car}_{i, t}^{Q \mathrm{QI}}$ is the variation in the abnormal return of the disclosure window for the quarterly information (QI) from the first quarter; $\triangle \mathrm{Car}_{i, t}^{\mathrm{OI}{ }^{2}}$ is the variation in the abnormal return of the disclosure window for the quarterly information (QI) from the second quarter; $\triangle \mathrm{Car}_{i, t}^{\mathrm{OI}} \mathrm{Q3}^{3}$ is the variation in the abnormal return of the disclosure window for the quarterly information (QI) from the third quarter; $\Delta$ Surp_ear is the variation in the earnings surprise; $\Delta$ Ear_dummy is a dummy variable that is 1 if the company had net earnings and 0 otherwise; $\triangle R O A$ is the variation in the return on assets; $\Delta / n \_M V$ is the variation in the Naperian logarithm of the company's market value. All the variations were calculated with relation to the same period of the previous year.

Source: Elaborated by the authors.

\subsection{Regression Results}

Table 8 presents the results of the regression of equation 1 , taking into consideration the full sample period. Considering that disclosure of KAMs became mandatory in 2016, the variations in the CAR were calculated for each one of the disclosure events of the companies from this period onward in relation to the previous period. Equation 1 seeks to verify whether, even controlling for other factors, the variations in the returns associated with disclosure of SFSs adopting KAMs have a greater association with the variation in the abnormal returns of other information disclosed by the company, whether mandatory or voluntary. The idea of this association is presented by Beyer et al. (2010) in an evaluation of the quarterly break-down of the variance in the return of American companies in relation to their disclosure events. The research design was adapted to try and identify whether the inclusion of KAMs in the disclosure of SFSs would provide any additional information to the market. Thus, the variations in the cumulative returns of the disclosure events were used, considering that when there is an increase in information, the coefficient relating to the new information provided by the KAMs contained in the SFSs should be significant and greater than the coefficient of the other information disclosed by the companies, especially the interim financial statements that do not have a full independent auditor's report.

Based on Table 8 , and in line with the research hypothesis, we have a coefficient of the ${ }_{\Delta} \mathrm{Car}_{i, t}^{\mathrm{SFS}}$ variable of 2.44 , which is significant at $1 \%$, showing a positive effect on the association between the variation in the return around the SFS disclosure and the variation in the cumulative return for the year, suggesting that much 
of the variability in the returns on a company's stocks derives from the returns occurring around the date of the SFS disclosure. The coefficient comparison tests $\left(\beta_{1}>\beta_{n}>0\right)$ show that the results are stronger for the differences between the coefficients of the SFS and third quarter information, other mandatory information, and voluntary information. Thus, evidence is found that the disclosure of SFSs with the new content of the independent auditor's report from 2016 onward has informational content that is additional to the other mandatory and voluntary disclosure events analyzed in this study. The coefficient relating to the mandatory disclosure is 0.57 and significant at $1 \%$. It is also observed that the coefficients of the disclosure window of the first and second quarters are significant, while the coefficient relating to the voluntary disclosures is not significant.

Table 8

Results of the regression

\begin{tabular}{|c|c|c|c|c|c|c|}
\hline $\begin{array}{l}\text { Dep. variable } \\
{ }_{\Delta \mathrm{Car}_{\mathrm{i}, \mathrm{t}}^{\mathrm{ANO}}}\end{array}$ & Coefficient & $\begin{array}{c}\text { Robust standard } \\
\text { error }\end{array}$ & $t$ & $p>|t|$ & & \\
\hline Constant & $11.66^{* *}$ & 4.37 & 2.67 & 0.01 & 3.06 & 20.27 \\
\hline$\Delta \mathrm{Car}_{\mathrm{i}, \mathrm{t}}^{\mathrm{SFS}}(\%)$ & $2.44^{* * *}$ & 0.41 & 5.97 & 0.00 & 1.63 & 3.24 \\
\hline$\Delta \mathrm{Car}_{0}^{\mathrm{VD}}(\%)$ & 0.05 & 0.15 & 0.31 & 0.76 & -0.26 & 0.35 \\
\hline${ }_{\Delta} \mathrm{Car}_{0}^{\mathrm{OD}}(\%)$ & $0.57^{* * *}$ & 0.07 & 8.13 & 0.00 & 0.43 & 0.71 \\
\hline$\Delta \mathrm{Car}_{i, \mathrm{t}}^{\mathrm{OP} \mathrm{QI}}(\%)$ & $1.94^{* *}$ & 0.70 & 2.79 & 0.01 & 0.57 & 3.32 \\
\hline$\Delta \operatorname{Car}_{i, t}^{\mathrm{OQ} \mathrm{Q} 2}(\%)$ & $1.61^{*}$ & 0.89 & 1.82 & 0.07 & -0.14 & 3.35 \\
\hline$\Delta \operatorname{Car}_{\mathrm{i}, \mathrm{t}}^{\mathrm{OQ} \mathrm{Q} 3}(\%)$ & 0.01 & 0.60 & 0.02 & 0.98 & -1.17 & 1.20 \\
\hline$\Delta$ Surp_ear (\%) & 0.28 & 0.23 & 1.2 & 0.23 & -0.18 & 0.73 \\
\hline$\Delta$ Ear_dummy & -0.98 & 9.96 & -0.1 & 0.92 & -20.61 & 18.65 \\
\hline$\Delta$ roa $(\%)$ & -0.03 & 0.42 & -0.08 & 0.94 & -0.86 & 0.80 \\
\hline$\Delta \mathrm{ln} \_V M$ & $38.20^{* *}$ & 17.01 & 2.25 & 0.03 & 4.67 & 71.72 \\
\hline Adj. $R^{2}(\%)$ & \multicolumn{6}{|c|}{58.12} \\
\hline F-Stat & \multicolumn{6}{|c|}{32.67} \\
\hline Obs. & \multicolumn{6}{|c|}{225} \\
\hline
\end{tabular}

Note: This table presents the coefficient, $p$-value, and significance of the regression model of equation 1. The variables refer to company $i$, year $t$, and are expressed in percentages, with the exception of the $\Delta$ Ear_dummy and $\Delta / n_{-}$VM variables. $\Delta$ Car $r_{\mathrm{i}, t}^{\mathrm{YEAR}}$, $\triangle \mathrm{Car}_{i, t}^{S F S},{ }_{\mathrm{Car}}^{\mathrm{VD}},{ }_{\mathrm{Car}}{ }^{O D}$ and $\triangle \mathrm{Car}_{i, t}^{\mathrm{OI} Q 1}, \Delta \mathrm{Car}_{i, t}^{\mathrm{OI} Q 2}, \Delta \mathrm{Car}_{i, t}^{\mathrm{OI} Q 3}$ are the metrics used to capture the variation in the abnormal return of the

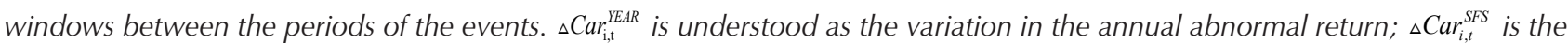
variation in the abnormal return on stock $i$ in the disclosure window of the annual standardized financial statement; $\Delta$ Car ${ }_{0}^{D D}$ is the variation in the abnormal returns of the windows in which there was voluntary disclosure of information; $\triangle C^{O A}{ }_{0}^{O D}$ is the variation in the abnormal returns of the windows in which there was mandatory disclosure; ${ }_{\triangle}$ Car ${ }_{i, t}^{\text {OI }}$ i is the variation in the abnormal return of the disclosure window for the quarterly information (QI) from the first quarter; ${ }_{\mathrm{C}} \mathrm{Car}_{i, t}^{\mathrm{OI}} \mathrm{Q2}^{2}$ is the variation in the abnormal return of the disclosure window for the quarterly information (QI) from the second quarter; $\triangle C_{1, t}{ }^{\text {II }}$ is the variation in the abnormal return of the disclosure window for the quarterly information (QI) from the third quarter; $\Delta$ Surp_ear is the variation in the earnings surprise; $\triangle$ Ear_dummy is a dummy variable that is 1 if the company had net earnings and 0 otherwise; $\triangle R O A$ is the variation in the return on assets; $\Delta / n_{-} M V$ is the variation in the Naperian logarithm of the company's market value. All the variations were calculated with relation to the same period of the previous year. The Winsor method was used to minimize the effect of the outliers on the ROA variable $(2.5 \%$ in each tail of the distribution).

$*, * *, * * *=10,5$, and $1 \%$ significance level, respectively.

C195\% $=95 \%$ confidence interval.

Source: Elaborated by the authors. 
The coefficients of the $\Delta \mathrm{Car}_{\mathrm{i}, \mathrm{O}}^{\mathrm{OI}}, \Delta \mathrm{Car}_{\mathrm{i}, \mathrm{t}}^{\mathrm{OI}}$, and $\Delta \mathrm{Car}_{\mathrm{i}, \mathrm{t}}^{\mathrm{OI} \mathrm{Q}}$ variables are responsible for capturing the association of the variation in the abnormal return around the disclosure windows for the quarterly reports. The differences between the coefficients found for $\Delta \mathrm{Car}_{\mathrm{i}, \mathrm{t}}^{\mathrm{SFS}}$ and $\Delta \mathrm{Car}_{\mathrm{i}, \mathrm{t}}^{\mathrm{OI} \mathrm{Q} 1}, \Delta \mathrm{Car}_{\mathrm{i}, \mathrm{t}}^{\mathrm{OI} 2}$ and $\Delta \mathrm{Car}_{\mathrm{i}, \mathrm{t}}^{\mathrm{OP} \mathrm{Q} 3}$ are positive, but significant only in the case of the third quarter.

In general, the results suggest that the KAMs have informational relevance and contribute to the investors' analyses. These results are aligned with Christensen et al. (2014), who state that investors who receive a KAM paragraph are more likely to change their investment decisions than investors who receive a standardized audit report; in other words, they increase the confidence theory of Cordos and Fülöp (2015).

In addition, Table 9 presents the comparison between the result of the regression, considering the periods from 2015 to 2016 (first adoption period) and 2016 to 2017 as subsamples of the previous analysis.

Table 9

Results of the regression - Comparison between 2016 and 2017

\begin{tabular}{|c|c|c|c|c|}
\hline \multirow{2}{*}{$\begin{array}{l}\text { Dep. var.: } \\
{ }_{\triangle \text { Car }_{i, t}}^{\text {YEAR }}\end{array}$} & \multicolumn{2}{|c|}{ 2016-2015 } & \multicolumn{2}{|c|}{ 2017-2016 } \\
\hline & Coefficient & p-value & Coefficient & p-value \\
\hline$\Delta \operatorname{Car}_{i, t}^{\mathrm{SFS}}(\%)$ & $2.42^{* * *}$ & 0.00 & $2,09 * * *$ & 0,00 \\
\hline${ }_{\Delta} \operatorname{Car}_{0}^{V D}(\%)$ & 0.02 & 0.72 & 0.13 & 0.41 \\
\hline${ }_{\Delta} \operatorname{Car}_{0}{ }^{\mathrm{OD}}(\%)$ & $0.62^{* * *}$ & 0.00 & $0.37^{* * *}$ & 0.00 \\
\hline$\Delta \operatorname{Car}_{\mathrm{i}, \mathrm{t}}^{\mathrm{QI} \mathrm{Ql}}(\%)$ & $2.52^{* * *}$ & 0.00 & 0.98 & 0.11 \\
\hline$\Delta \operatorname{Car}_{\mathrm{i}, \mathrm{t}}^{\mathrm{Q} \mathrm{Q} \mathrm{Q}^{2}}(\%)$ & $2.35^{* *}$ & 0.04 & -0.24 & 0.62 \\
\hline$\Delta \operatorname{Car}_{\mathrm{i}, \mathrm{t}}^{\mathrm{QIQ}}(\%)$ & -0.01 & 0.99 & $1.21^{* *}$ & 0.02 \\
\hline$\Delta$ Surp_ear (\%) & 0.24 & 0.99 & -0.01 & 0.99 \\
\hline$\Delta$ Ear_dummy & 0.98 & 0.94 & $17.86^{* *}$ & 0.07 \\
\hline$\Delta$ roa $(\%)$ & 0.075 & 0.87 & $-1.21^{* * *}$ & 0.00 \\
\hline$\Delta \mathrm{ln} \_\mathrm{MV}$ & 34.12 & 0.28 & $48.01^{* * *}$ & 0.00 \\
\hline Constant & $18.38^{* * *}$ & 0.00 & -5.95 & 0.291 \\
\hline Adj. R² (\%) & \multicolumn{2}{|c|}{63.79} & \multicolumn{2}{|c|}{55.74} \\
\hline F-Stat & \multicolumn{2}{|c|}{28.63} & \multicolumn{2}{|c|}{11.92} \\
\hline Obs. & \multicolumn{2}{|c|}{131} & \multicolumn{2}{|c|}{94} \\
\hline
\end{tabular}

Note: This table presents the coefficient, $p$-value, and significance of the regression model of equation 1. The variables refer to company $i$, year $t$, and are expressed in percentages, with the exception of the $\Delta$ Ear_dummy and $\Delta / n_{-}$VM variables. $\Delta C a r_{\mathrm{i}, \mathrm{t}}^{\mathrm{YEAR}}$,

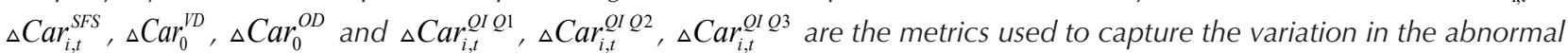
return of the windows between the periods of the events. ${ }_{\Delta}$ Car $_{\mathrm{i}, \mathrm{t}}^{\mathrm{YEAR}}$ is understood as the variation in the annual abnormal return; ${ }_{\triangle} \mathrm{Car}_{i, t}^{S F S}$ is the variation in the abnormal return on stock $i$ in the disclosure window of the annual standardized financial statement; ${ }_{\triangle} \mathrm{Car}_{0}^{V D}$ is the variation in the abnormal returns of the windows in which there was voluntary disclosure of information; ${ } C{ }{ }^{O D}{ }_{0}$ is the variation in the abnormal returns of the windows in which there was mandatory disclosure; ${ }_{\Delta}$ Car $r_{i, t}^{Q I}{ }^{O 1}$ is the variation in the abnormal return of the disclosure window for the quarterly information (QI) from the first quarter; ${ }_{\Delta} C_{\text {ar }}^{Q I} Q^{2}$ is the variation in the abnormal return of the disclosure window for the quarterly information (QI) from the second quarter; $\Delta$ Car $_{i, t}^{Q I} Q^{3}$ is the variation in the abnormal return of the disclosure window for the quarterly information (QI) from the third quarter; $\triangle$ Surp_ear is the variation in the earnings surprise; $\triangle$ Ear_dummy is a dummy variable that is 1 if the company had net earnings and 0 otherwise; $\triangle R O A$ is the variation in the return on assets; $\triangle I n \_M V$ is the variation in the Naperian logarithm of the company's market value. All the variations were calculated with relation to the same period of the previous year. The Winsor method was used to minimize the effect of the outliers on the ROA variable $(2.5 \%$ in each tail of the distribution).

$*, * *, * * *=10,5$, and $1 \%$ significance level, respectively.

Source: Elaborated by the authors. 
Table 9 also shows that the coefficient of the $\Delta \mathrm{Car}_{i, t}^{\mathrm{SFS}}$ variable is significant for both subsamples and its coefficient shows that, in the first year of the inclusion of KAMs, there was a greater variation around the SFS disclosure window than in the following year. It is also noted that the coefficient of the ${ }_{\Delta} \mathrm{Car}_{0}{ }^{\mathrm{DD}}$ variable in both periods is significant at $1 \%$. From carrying out the coefficient comparison tests $\left(\beta_{1}>\beta_{n}>0\right)$, we can see that for both subsamples the coefficient of the SFS disclosure is greater than the coefficients of the voluntary and mandatory information, but there are results that vary when compared with the coefficients of the information disclosed in the quarterly reports. Thus, it can be seen that the accounting information disclosed in the quarterly reports is incorporated into the returns on the stocks, but the information disclosed in the SFSs including KAMs plays a relevant and consistent role in the composition of the cumulative abnormal returns on the Brazilian companies' stocks, and it is the only variable that maintained a significant coefficient in all the specifications.

\section{CONCLUDING REMARKS}

This paper aimed to empirically investigate whether the KAMs introduced in the independent auditor's report as of the 2016 fiscal year have provided informational relevance for investors in the Brazilian market. The informational relevance was analyzed using the cumulative abnormal return on the dates of the respective disclosure of the audit report.

In general, the results of this study indicate a positive and consistent association between the coefficient of the relationship between the variation in the cumulative abnormal returns in the disclosure window for the financial statements with the auditor's report that includes KAMs and the variation in the company's annual abnormal returns. In addition, we can observe some results that indicate an incremental positive association in relation to the association between the other financial information (mandatory and voluntary) and the variation in the returns from the same period.

This result supports this study's hypothesis, demonstrating that, since the disclosure of financial statements containing the audit report with KAMs, there has been a significant explanation of the cumulative abnormal returns in the year based on the cumulative returns around the SFS disclosure date.

According to the results indicated, it is verified that the inclusion of KAMs has informational relevance by comparing the behaviors of the abnormal returns with those obtained in the period immediately before. These results support the findings in the studies elaborated by Christensen et al. (2014) and Cordoş and Fülöp (2015) and go against the results found by Bédard et al. (2014).

This paper fills a gap in the literature, based on its empirical evidence regarding the informational relevance of the content of the audit report, especially from the adoption of KAMs, considering that many studies elaborated on the topic with an emphasis on informational relevance have been based on applying questionnaires to students.

Standing out as a limitation of these results is the possibility of there being other non-controlled effects that influenced the volatility of the stock prices and their respective daily returns. It is also worth highlighting that some comparison tests of the coefficients associated with the disclosure of the SFSs and QI reports were not significant, showing that the quarterly accounting information, even if it is not fully audited, has relevance for the market agents.

For new studies, we suggest widening the results detected in this study, especially by working with more periods and comparing the information that is repeating in the following years, or even verifying whether the auditing firms are following a standard and using the same KAM texts for other companies they audit. Another important factor to be analyzed is whether the auditor's independence is being influenced with the scope of the audit report, as foreseen in the studies by Brown et al. (2014) and Gimbar, Hasen, and Ozlanski (2016).

\section{REFERENCES}

Ball, R., \& Shivakumar, L. (2008). How much new information is there in earnings? Journal of Accounting Research, 46(5), 975-1016.

Bédard, J., Gonthier-Besacier, N., \& Schatt, A. (2014). Costs and benefits of reporting key audit matters in the audit report: The French experience. Retrieved from http://www.isarhq.
org/2014_downloads/papers/ISAR2014_Bedard_Besacier_ Schatt.pdf

Beyer, A., Cohen, D. A., Lys, T. Z., \& Walther, B. R. (2010). The financial reporting environment: Review of the recent literature. Journal of Accounting and Economics, 50(2), 296343. 
Brasel, K., Doxey, M. M., Grenier, J. H., \& Reffett, A. (2016). Risk disclosure preceding negative outcomes: The effects of reporting critical audit matters on judgments of auditor liability. The Accounting Review, 91(5), 1345-1362.

Brown, S., \& Hillegeist, S. A. (2007). How disclosure quality affects the level of information asymmetry. Review of Accounting Studies, 12(2-3), 443-477.

Brown, T., Majors, T. M., \& Peecher, M. E. (2014). The influence of evaluator expertise, a judgment rule, and critical audit matters on assessments of auditor legal liability Retrieved from https://www.researchgate.net/ publication/272300283_The_Influence_of_Evaluator_ Expertise_a_Judgment_Rule_and_Critical_Audit_ Matters_on_Assessments_of_Auditor_Legal_Liability. publication/272300283_The_Influence_of_Evaluator_ Expertise_a_Judgment_Rule_and_Critical_Audit_Matters_ on_Assessments_of_Auditor_Legal_Liability

Carson, E., Fargher, N. L., Geiger, M. A., Lennox, C. S., Raghunandan, K., \& Willekens, M. (2013). Audit reporting for going-concern uncertainty: A research synthesis [Supplement]. Auditing: A Journal of Practice \& Theory, 32(1), 353-384.

Christensen, B. E., Glover, S. M., \& Wolfe, C. J. (2014). Do critical audit matter paragraphs in the audit report change nonprofessional investors' decision to invest? Auditing: A Journal of Practice \& Theory, 33(4), 71-93.

Comissão de Valores Mobiliários (Brazilian Securities and Exchange Commission). (2002). CVM Instruction n. 358, of January $3^{\text {rd }}$ of 2002. Discusses the disclosure and use of information about relevant acts or facts relating to publiclyheld companies, regulates the disclosure of information on the trading of securities and acquisition of a significant amount of stocks issued by a publicly-held company, establishes limits and conditions for trading stocks of a publicly-held company pending a relevant fact not disclosed to the market, revokes CVM Instruction n. 31, of February $8^{\text {th }}$ of 1984 , CVM Instruction n. 69, of September $8^{\text {th }}$ of 1987 , art. 3 of CVM Instruction n. 229 , of January $16^{\text {th }}$ of 1995 , the single paragraph of art. 13 of CVM Instruction n. 202, of December $6^{\text {th }}$ of 1993, and arts. 3 and 11 of CVM Instruction n. 299, of February 1999, and makes other arrangements. Retrieved from http://www.cvm.gov.br/export/sites/cvm/legislacao/ instrucoes/anexos/300/inst358.pdf

Comissão de Valores Mobiliários (Brazilian Securities and Exchange Commission). (2009). CVM Instruction n. 480, of December $7^{\text {th }}$ of 2009. Discusses the registering of issuers of securities accepted for trading in regulated securities markets. Retrieved from file://C:/Users/User/Downloads/inst480.pdf

Conselho Federal de Contabilidade (Federal Accounting Council). (2013). Norma Brasileira de Contabilidade Brazilian Accounting Law n. 18, of July $26^{\text {th }}$ of 2013 . Discusses the disclosure of the independent auditor's report and auditing procedures required when resubmitting accounting statements or interim information. Retrieved from http:// www.normaslegais.com.br/legislacao/nbc-cta-18-2013.htm

Conselho Federal de Contabilidade (Federal Accounting Council). (2016a). Brazilian Accounting Standard n. 705, of June $17^{\text {th }}$ of 2016. Gives new wording to NBC TA 705, which discusses modifications in the independent auditor's opinion. Retrieved from https://www.legisweb.com.br/ legislacao/?id=325607

Conselho Federal de Contabilidade (Federal Accounting Council). (2016b). Brazilian Accounting Standard n. 260, of July $4^{\text {th }}$ of 2016 . Gives new wording to NBC TA 260 (R1), which discusses communication with those responsible for governance. Retrieved from http://www2.cfc.org.br/sisweb/ sre/detalhes_sre.aspx?Codigo=2016/NBCTA260R2

Conselho Federal de Contabilidade (Federal Accounting Council). (2016c). Brazilian Accounting Standard n. 570, of June $17^{\text {th }}$ of 2016. Gives new wording to NBC TA 570, which discusses operational continuity. Retrieved from https://www. legisweb.com.br/legislacao/?id=325582

Conselho Federal de Contabilidade (Federal Accounting Council). (2016d). Brazilian Accounting Standard n. 700, of June $17^{\text {th }}$ of 2016. Gives new wording to NBC TA 700, which discusses the formation of an opinion and disclosure of the independent auditor's report regarding the accounting statements. Retrieved from https://www.legisweb.com.br/ legislacao/?id=325605

Conselho Federal de Contabilidade (Federal Accounting Council). (2016e). Brazilian Accounting Standard n. 701, of June $17^{\text {th }}$ of 2016. Communication of the Key Audit Matters in the Independent Auditor's Report. Retrieved from https:// www.legisweb.com.br/legislacao/?id=325606

Conselho Federal de Contabilidade (Federal Accounting Council). (2016f). Brazilian Accounting Standard n. 706, of June $17^{\text {th }}$ of 2016. Gives new wording to NBC TA 706, which discusses the paragraphs of emphasis and paragraphs on other subjects in the independent auditor's report. Retrieved from https://www.legisweb.com.br/legislacao/?id=325608

Cordoş, G. S., \& Fülöp, M. T. (2015). Understanding audit reporting changes: introduction of key audit matters. Accounting \& Management Information Systems, 14(1), 128-152.

Costa, C. M., Galdi, F. C., Motoki, F. Y., \& Sanchez, J. M. (2016). Non-compliance in executive compensation disclosure: the Brazilian Experience. Journal of Business Finance \& Accounting, 43(3-4), 329-369.

DeFond, M., \& Zhang, J. (2014). A review of archival auditing research. Journal of Accounting and Economics, 58(2-3), 275326.

Deloitte. (2013). Comment Letter. PCAOB Rulemaking Docket n. 034. PCAOB. Retrieved from https://dart.deloitte.com/ USDART/resource/77a915e1-3f1d-11e6-95db-e34a20324c80

Demaki, G. O. (2011). Proliferation of codes of corporate governance in Nigeria and economic development. Business and Management Review, 1(6), 1-7.

Dobija, D., Cieślak, I., Iwuć, K. (2013). Extended audit reporting - An insight from the auditing profession in Poland. Social Science Research Network. Retrieved from http://dx.doi. org/10.2139/ssrn.2215605

Elliott, W. B., Fanning, K., \& Peecher, M. E. (2016). Do investors value financial reporting quality beyond estimated fundamental value? And, can better audit reports unlock this value? University of Illinois. Retrieved from https://community. 
bus.emory.edu/FacultySeminars/Shared\%20Documents/ Peecher,\%20Mark\%20-\%20workshop\%20paper.pdf

Ghosh, A., \& Moon, D. (2005). Auditor tenure and perceptions of audit quality. The Accounting Review, 80(2), 585-612.

Gimbar, C., Hansen, B., \& Ozlanski, M. E. (2016). The effects of critical audit matter paragraphs and accounting standard precision on auditor liability. The Accounting Review, 91(6), 1629-1646.

Healy, P. M., \& Palepu, K. G. (2001). A review of the voluntary disclosure literature. Journal of Accounting and Economics, 31(1-3), 405-440.

Heflin, F. L., Shaw, K. W., \& Wild, J. J. (2005). Disclosure policy and market liquidity: Impact of depth quotes and order sizes. Contemporary Accounting Research, 22(4), 829-865.

Instituto dos Auditores Independentes do Brasil (Institute of Independent Auditors of Brazil). (2013). IAASB divulga propostas para novo relatório do auditor. Instituto dos Auditores Independentes do Brasil. Retrieved from http:// www.ibracon.com.br/ibracon/Portugues/detNoticia. php? cod $=1313$

Jensen, M. C., \& Meckling, W. H. (1976). Theory of the firm: Managerial behavior, agency costs and ownership structure. Journal of Financial Economics, 3(4), 305-360.

Köhler, A., Ratzinger-Sakel, N. V., \& Theis, J. (2016). The effects of key audit matters on the auditor's report's communicative value: Experimental evidence from investment professionals and non-professional investors. Social Science Research Network. Retrieved from https://papers.ssrn.com/sol3/papers. cfm?abstract_id=2838162

Lennox, C. S., Schmidt, J. J., \& Thompson, A. (2018). Is the expanded model of audit reporting informative to investors? Evidence from the UK. Social Science Research Network. Retrieved from https://ssrn.com/abstract=2619785

Locatelli, O. (2016). Impacto da evidenciação de informações no valor das ações das sociedades de economia mista (Master's Dissertation). Fundação Instituto Capixaba de Pesquisas em Contabilidade, Economia e Finanças, Vitória.

Longo, C. G. (2017). Relatórios de auditoria. São Paulo, SP: Trevisan.

Lopes, A. B., \& Martins, E. (2005). Teoria da contabilidade: uma nova abordagem. São Paulo, SP: Atlas.
Malaquias, R. F., \& Lemes, S. (2015). Evidenciação e volatilidade: testes com equações estruturais. Revista de Administração e Contabilidade da Unisinos, 12(2), 96-109.

Piot, C. (2001). Agency costs and audit quality: Evidence from France. European Accounting Review, 10(3), 461-499.

Porter, B., \& Gowthorpe, C. (2004). Audit expectationperformance gap in the United Kingdom in 1999 and comparison with the gap in New Zealand in 1989 and in 1999. The Institute of Chartered Accountants of Scotland. Retrieved from http://citeseerx.ist.psu.edu/viewdoc/ download?doi=10.1.1.474.1715\&rep=rep1\&type $=$ pdf

Public Company Accounting Oversight Board. 2013. PCAOB Release n. 2013-005, PCAOB Rulemaking Docket Matter n. 034. PCAOB. Retrieved from https://pcaobus.org/ Rulemaking/Docket034/Release_2013-005_ARM.pdf

Reiter, N., \& Procianoy, J. L. (2013). Impacto informacional das reuniões públicas Apimec: um estudo de evento. RAM Revista de Administração Mackenzie, 14(2), 127-154.

Silva, F. J., \& Dantas, J. A. (2018). Principais assuntos de auditoria no novo relatório de auditoria nas instituições financeiras brasileiras (Monograph). Universidade de Brasília, Brasília.

Sirois, L. P., Bédard, J., \& Bera, P. (2018). The informational value of key audit matters in the auditor's report: Evidence from an eye-tracking study. Accounting Horizons, 32(2), 141-162.

Souza, P. R. E. B. (1995). Análise do atual estágio de disclosure das companhias abertas no mercado de capitais brasileiro e contribuições para o seu aprimoramento (Master's Dissertation). Universidade de São Paulo, São Paulo.

Takamatsu, R. T., Lamounier, W. M., \& Colauto, R. D. (2008). Impactos da divulgação de prejuízos nos retornos de ações de companhias participantes do Ibovespa. Revista Universo Contábil, 4(1), 46-63.

Tepalagul, N., \& Lin, L. (2015). Auditor independence and audit quality: A literature review. Journal of Accounting, Auditing \& Finance, 30(1), 101-121.

Vanstraelen, A., Schelleman, C., Meuwissen, R., \& Hofmann, I. (2012). The audit reporting debate: Seemingly intractable problems and feasible solutions. European Accounting Review, 21(2), 193-215.

Verrecchia, R. E. (2001). Essays on disclosure. Journal of Accounting and Economics, 32(1-3), 97-180. 